\title{
CUL2 Gene
}

National Cancer Institute

\section{Source}

National Cancer Institute. CUL2 Gene. NCI Thesaurus. Code C24322.

This gene is involved in protein degradation and the negative regulation of cell proliferation. 